\title{
Structural characterization, reproductive phenology and anthropogenic disturbance of mangroves in Costa do Sol, Bons Sinais Estuary and Pemba-Metuge from Mozambique
}

\section{FAURA M. C. AMADE ${ }^{1,2}$, PAXIE W. CHIRWA ${ }^{2}$, MÁRIO P. FALCÃO ${ }^{1}$ AND CAREL J. OOSTHUIZEN ${ }^{3}$}

\author{
'Department of Forestry Engineering, Eduardo Mondlane University, P.O. Box 257, \\ Maputo, Mozambique \\ ${ }^{2}$ Forest Science Postgraduate Programme, Department of Plant and Soil Sciences, \\ University of Pretoria, Pretoria, South Africa \\ ${ }^{3}$ Department of Zoology and Entomology, University of Pretoria, Private Bag X20, \\ Hatfield, 0028, South Africa
}

\begin{abstract}
Mangrove forests are among the most important ecosystems with high ecological and economic value. In order to better understand and conserve this ecosystem, we aim to provide an overview of mangrove structure along the southern, central and northern parts of Mozambique, in Costa do Sol (CS), Bons Sinais Estuary (BSE) and Pemba-Metuge $(P M)$, respectively. A total of 10 plots $/$ site $(10 \times 10 \mathrm{~m})$ along a transect perpendicular to the seashore were used. Inside the plots, the stem diameter and height were measured, and the species identified. The phenology and deforestation were categorized, and dead stumps were identified by species and its diameter measured. A total of five mangrove
\end{abstract}

CONTACT Faura M. C. Amade, Email: fauracangy@uem.mz; fauracangy@gmail.com, Department of Forestry Engineering, Eduardo Mondlane University, 3453, P.O. Box 257, Maputo, Mozambique. 
species were observed at BSE, four at PM and three at CS. BSE presented the greatest mean height at $3.3 \mathrm{~m}$, as well as the highest complexity at 22.7. Avicennia marina was identified as the most ecologically important species in all the study sites. During May, A. marina trees were mainly dormant, while those of Ceriops tagal and Rhizophora mucronata were flowering and fruiting. Intact trees were dominant in all the study sites. This study will contribute in designing and implementation of sustainable strategies for conservation of mangrove forests in Mozambique.

Keywords: Mangrove management, flowering, anthropogenic, Mozambique

\section{INTRODUCTION}

Mangrove forests are among the most productive ecosystems and the species are adapted for survival between land and sea in tropical and sub-tropical regions (Barnuevo et al., 2017; Brown et al., 2018). Mangroves are a functional group characterized by possession of common morphological, biochemical, physiological, and reproductive adaptations that allow them to develop in saline and hypoxic environments (PastorGuzman, Dash, \& Atkinson, 2018). Some of the most important characteristics include aerial roots, the ability to eliminate excess salts through salt glands, retention of nutrients and vivipary (Sahu, Singh, \& Kathiresan, 2016; Garcia, Dalmolin, França, \& Mangabeira, 2017). Mangrove phenology provides important information about species interactions within communities and overall community function (Fenner, 1998; Wang'ondu et al., 2013).

Mangroves are ecologically and socially important. They provide food, habitat and nursery areas for fish, crustaceans and molluscs. This makes them a valuable economic resource for coastal populations (Ferreira \& Lacerda, 2016; Himes-Cornell, Pendleton, \& Atiyah, 2018). In addition, they also provide wood for house and boat construction, 
provision of household firewood and charcoal, medicinal purposes and fiber extraction for paper (Dos Santos \& Lana, 2017). Mangroves play a crucial role in the sequestration of atmospheric carbon with an estimated global average of $409 \mathrm{Mg}$ carbon.ha $^{-1}$ (HimesCornell, Pendleton, \& Atiyah, 2018). In 1997, the financial capital provided by mangrove ecosystem services was estimated at approximately US $\$ 1.6$ billion each year, globally (Brown et al., 2018). Despite their elevated importance, at least 35\% of mangroves have been destroyed worldwide due to overexploitation, conversion into salt- or aquaculture ponds (Ferreira \& Lacerda, 2016), and their removal for human settlement expansion (Ferreira \& Lacerda, 2016; Himes-Cornell, Pendleton, \& Atiyah, 2018). This has occurred specifically in Mozambique where mangrove forests were lost mainly due to clearance of these forests for the construction of salt ponds and dams, agriculture, aquaculture, urban development, and for firewood as well as for making charcoal (Fatoyinbo, Simard, Washington-Allen, \& Shugart, 2008; Bandeira et al., 2009).

Africa contains approximately $20 \%$ of the global mangrove forests with Mozambique containing approximately $2.3 \%$. Mozambique is ranked $13^{\text {th }}$ in Africa when it comes to the country with the highest mangrove coverage and has the second largest area of mangrove cover, spanning 277,000 ha along the Indian Ocean coastline (Fatoyinbo, Simard, Washington-Allen, \& Shugart, 2008; Stringer, Trettin, Zarnoch, \& Tang, 2015). The total area of mangrove cover in Mozambique was estimated at 290,900 ha (Fatoyinbo, Simard, Washington-Allen, \& Shugart, 2008). The largest mangrove area is in the Save-Zambezi River complex in the central provinces of Sofala and Zambézia, with a total mangrove area of 190,000 ha. The southern provinces, Maputo and Inhambane, have 600 and 1,300 ha respectively, and the northern province of Cabo Delgado, 2,790 ha (Fatoyinbo, Simard, Washington-Allen, \& Shugart, 2008). 
Studies regarding the structural attributes and the conservation status of mangrove forests in Mozambique, using ground measurements, were conducted in the southern parts of Mozambique, specifically in the Maputo Bay area, Inhaca Island and the Espirito Santo Estuary (Amade, 2006, 2008; Bandeira et al., 2009). Studies in the northern parts focussed on Pemba and Mecufi (Bandeira et al., 2009). There are no published studies from the remaining mangrove zones other than Fatoyinbo, Simard, Washington-Allen, \& Shugart (2008) who studied changes in mangrove forest cover across Mozambican provinces by using Landsat ETM+ and Shuttle Radar Topography Mission (SRTM) data. The main objective of this study was to understand the current structure of mangrove forests for selected sites in Mozambique. This study aimed to answer the following questions: (1) what is the structure of mangrove forests in terms of the importance of species, structural attributes (diameter and height) and index of complexity in the three study sites? (2) What is the pattern of the reproductive phenology and does it differ among the species? (3) What is the level of anthropogenic disturbance in the study sites, and which species are the most susceptible? and (4) What is the regeneration pattern of the different species?

Understanding mangrove structure and ecology in Mozambique is still poor and therefore more studies are needed to improve the knowledge about this important resource to assist in designing good strategies for its conservation.

\section{METHODOLOGY}

\section{Study Sites}

The study was conducted at the following sites: Costa do Sol (CS) in Maputo Bay (Maputo Province) in the south of Mozambique, Bons Sinais Estuary (BSE) in Quelimane district (Zambezia province) in the center, and Pemba-Metuge (PM) in Pemba-Metuge district (Cabo Delgado province) in the northern part of the country (Figure 1). 


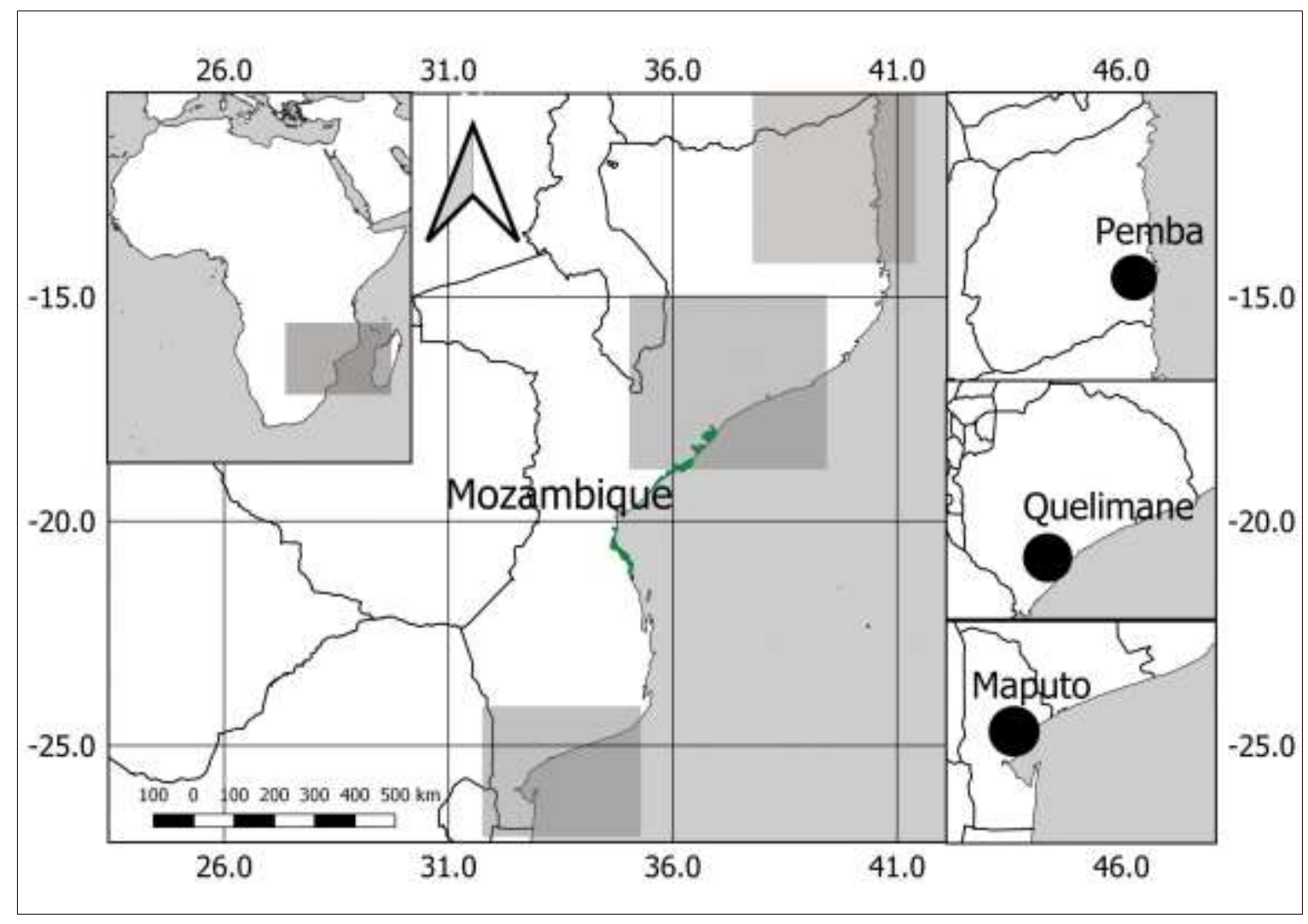

Figure 1. The locations for the three study sites Costa do So (CS) in Maputo bay (Maputo Province) in the south of Mozambique, Bons Sinais Estuary (BSE) in the Quelimane district (Zambezia province) in the center; and Pemba-Metuge (PM) at Pemba-Metuge district on the eastern side of Pemba city (Cabo Delgado province) in the north. Mangrove cover along the coast in central Mozambique (Indicated by green markings) were reported by Giri et al. (2013)

Mozambique has two seasons, the rainy season that is warm and humid between November and March, and a cooler dryer season over the rest of the year. The temperature normally varies between $20^{\circ}$ to $39^{\circ} \mathrm{C}$ (Sengo et al., 2005; Canhanga \& Dias, 2005).

Costa do Sol mangrove forest is characterized by a small and shallow seawater swamp situated about $7 \mathrm{~km}$ north of Maputo city and covers nearly 200 ha ( $\left.25^{\circ} 55^{\prime} \mathrm{S}, 32^{\circ} 35^{\prime} \mathrm{E}\right)$. The mangrove creek is bordered by a residential area. The maximum tidal amplitude is about 3.5 m (Litulo, 2005a; Cannici et al., 2009; Penha-Lopes et al., 2011). The mean 
daily air temperature varies from $17^{\circ} \mathrm{C}$ to $27^{\circ} \mathrm{C}$, from winter to summer, and the mean annual rainfall is $884 \mathrm{~mm}$ (Canhanga \& Dias, 2005) (Figure 1).

Bons Sinais Estuary is located, between the confluence of Cuácua and Licuári rivers and the Mozambican Channel in the Indian Ocean (18 01' S, 36 51' E) (Mocuba, 2010; Mazzilli, 2015). The mangrove extension at Zambezia province was estimated to be 82,000 ha in 2002, representing almost half of the mangrove cover lost since 1972 (Fatoyinbo, Simard, Washington-Allen, \& Shugart, 2008). The estuary is also the entrance to the port of Quelimane City, $20 \mathrm{~km}$ inland. A dense mangrove forest extends along the banks of the BSE (Mocuba, 2010). There is currently no information available regarding the size of this mangrove forest. The mean annual precipitation is around $1,400 \mathrm{~mm}$. The annual temperature averages at around $25^{\circ} \mathrm{C}$. The domestic wastes from the city of Quelimane are discharged directly into the BSE. Industrial aquaculture activity occurs across from the city (Mocuba, 2010) (Figure1).

Pemba-Metuge district has Pemba City and the Indian Ocean on its eastern side $\left(12^{\circ} 58\right.$ 'S, $\left.40^{\circ} 24^{\prime} \mathrm{E}\right)$. The mangrove area is estimated at 4,630 ha. The mean annual precipitation ranges from 800 to $1,000 \mathrm{~mm}$ and an average annual temperature of $25^{\circ} \mathrm{C}$ (Utui et al., 2013). The PM mangrove forest is located close to an active fishing site and a rural residential area (Figure 1).

\section{Data Collection}

Sampling time was chosen randomly and took place during the month of May. Transects were established perpendicular to the waterline in order to cover all the zones that form part of the forest: the fringe, middle, and upper zone. A total number of 30 plots were marked for all three study sites with 10 plots per study site. Plots of $10 \mathrm{~m} \times 10 \mathrm{~m}$ were marked along each transect (Bosire, Dahdouh-Guebas, Kairo, \& Koedam, 2003; Kairo et 
al., 2008; Bandeira et al., 2009). The distance between plots was $\geq 10 \mathrm{~m}$ (maximum distance of $20 \mathrm{~m}$ ) depending on the landscape (dense vegetation, creeks, muddy and wet soil). Because mangroves, in general, have low species diversity and are similar in species composition (Fatoyinbo, Simard, Washington-Allen, \& Shugart, 2008), it was assumed that the number of plots marked would be sufficient to show the structure of mangroves in these study sites.

All the trees with a stem diameter greater than $2.5 \mathrm{~cm}$ were identified and counted within each plot. Tree stem diameter at $1.30 \mathrm{~m}$ above the ground (D130) (Brokaw \&Thompson, 2000) and tree height (m) were measured for each of these trees. Since Rhizophora tree species usually contain prop roots at $1.30 \mathrm{~m}$ above the ground level, stem diameters were taken at $30 \mathrm{~cm}$ above the highest prop root (Dahdouh-Guebas \& Koedam, 2006). We used this information for calculating stand density $(\mathrm{De})$ and basal area $(\mathrm{Ba})$ (Cintron \& Schaeffer-Novelli, 1984; Dahdouh-Guebas \& Koedam, 2006) (Equations 1, 2, and 3 from Appendix 1).

\section{Forest reproductive phenology}

Trees were classified into three classes based on their reproductive phenology: dormant (trees without any reproductive element); flowering (trees with flowers) and fruiting (trees with fruits only or with fruits and flowers simultaneously) (Tomlinson, 1986; Amade, 2006).

\section{Anthropogenic disturbance}

To assess the level of mangrove deforestation, living trees were categorized and harvested trees recorded. Individual living trees were counted and grouped into two categories: intact and partially cut trees. Intact trees corresponded to trees with no signs of cutting, whereas partially cut trees included trees with signs of lateral branch cutting 
(Bandeira et al. 2009). Harvested trees (dead stamps) were identified up to species level. The diameter was measured for all trees and the relative density $\left(\mathrm{De}_{\mathrm{r}}\right)$, relative dominance $\left(\mathrm{Do}_{\mathrm{ri}}\right)$ and relative frequency $\left(F_{\mathrm{ri}}\right)$ calculated (Cintron \& Schaeffer-Novelli, 1984).

\section{Forest regeneration}

Forest regeneration status was assessed inside $5 \mathrm{~m} \times 5 \mathrm{~m}$ subplots (within the $10 \mathrm{~m} \times 10$ $\mathrm{m}$ plots). Occurrence of juvenile trees for the different species were recorded and grouped into one of three regeneration classes $(\mathrm{RC})$ based on height: less than $40.0 \mathrm{~cm}$ $(R C \mathrm{I})$; between 40.1 and $150.0 \mathrm{~cm}(\mathrm{RC} \mathrm{II})$; and greater than $150.1 \mathrm{~cm}$ but less than 3.0 m (RC III) (Kairo et al., 2002; Bandeira et al., 2009).

\section{Data analysis}

Normality and homogeneity tests for variances were performed among the study sites. Due to the absence of a normal distribution for these data, Kruskal-Wallis tests were performed as well as post-hoc tests at a 0.05 probability level (Kairo et al., 2008; Bandeira et al., 2009).

The diameter and height measurements, phenological status (dormant, flowering or fruiting), anthropogenic effect (intact or partially cut) and the regeneration classes were compared among the three study sites. The diameter and height measurements were grouped according to Urrego, Molina, \& Suárez (2014), into eight and six classes respectively. The grouping was according to classes of use of the trees. In addition, the quantification of diameter distribution allows us to relate diameter to stand density, disturbances, and history of forests; thereby also determining the future trends of forest community structure (Sapkota, Stahl, \& Norton, 2018). 
The complexity index (C.I.) for each study site was obtained as the product of the number of species $(m)$, basal area (Ba), mean stand height $(\mathrm{h})$ and stem density (De) (Holdridge et al., 1971; Bosire, Dahdouh-Guebas, Kairo \& Koedam, 2003; Bandeira et al. 2009) (Equations 4 and 5 from Appendix 1).

The importance value (I.V.), which is a relative measure of the ecological contribution of a species, for all the mangrove species was calculated by summing each species' relative density $\left(\mathrm{De}_{\mathrm{r}}\right)$, relative dominance $\left(\mathrm{Do}_{\mathrm{ri}}\right)$ and relative frequency $\left(F_{\mathrm{ri}}\right)$ (Cintron and Schaeffer-Novelli, 1984; Curtis, 1959; Dahdouh-Guebas \& Koedam, 2006) (Equations 6, 7, 8 and 9 from Appendix 1).

\section{RESULTS}

\section{Forest structure}

Avicennia marina was identified as the most ecologically important species at all three study sites. CS was dominated by $A$. marina since it was the principal species with the highest relative dominance, density and frequency (Table 1).

Table 1. Structural attributes of the mangrove forests for the three study sites from this study as well as the information from Bandeira et al. (2009).

\begin{tabular}{|c|c|c|c|c|c|c|c|}
\hline \multirow{2}{*}{ Site } & \multirow{2}{*}{ Species } & \multirow{2}{*}{$\begin{array}{c}\text { Mean } \\
\text { height } \\
\text { (m } \pm \text { S.E.) }\end{array}$} & \multirow{2}{*}{$\begin{array}{c}\text { Mean } \\
\text { diameter } \\
\text { (cm } \pm \text { S.E.) }\end{array}$} & \multicolumn{3}{|c|}{ Relative values (\%) } & \multirow{2}{*}{ I.V. } \\
\hline & & & & Dominance & Density & Frequency & \\
\hline \multirow{3}{*}{$\begin{array}{l}\text { Costa do } \\
\text { Sol (CS) }\end{array}$} & $\begin{array}{c}\text { Avicennia } \\
\text { marina }\end{array}$ & $2.3 \pm 0.1$ & $5.4 \pm 0.3$ & 84.8 & 93.9 & 62.5 & 241.1 \\
\hline & Ceriops tagal & $0.6 \pm 0.2$ & $3.7 \pm 0.4$ & 0.8 & 2.8 & 12.5 & 16.1 \\
\hline & $\begin{array}{l}\text { Rhizophora } \\
\text { mucronata }\end{array}$ & $1.9 \pm 0.4$ & $10.6 \pm 4.6$ & 14.4 & 3.4 & 25 & 42.8 \\
\hline
\end{tabular}




\begin{tabular}{|c|c|c|c|c|c|c|c|}
\hline \multirow{5}{*}{$\begin{array}{c}\text { Bons Sinais } \\
\text { Estuary } \\
\text { (BSE) }\end{array}$} & $\begin{array}{c}\text { Avicennia } \\
\text { marina }\end{array}$ & $5.8 \pm 0.5$ & $18.6 \pm 2.8$ & 72.1 & 20.5 & 32 & 124.6 \\
\hline & Ceriops tagal & $1.9 \pm 0.6$ & $4.0 \pm 2.8$ & 1 & 9.3 & 24 & 34.4 \\
\hline & $\begin{array}{l}\text { Rhizophora } \\
\text { mucronata }\end{array}$ & $2.4 \pm 0.1$ & $4.7 \pm 0.5$ & 15.8 & 58.6 & 20 & 94.4 \\
\hline & $\begin{array}{l}\text { Xilocarpus } \\
\text { granatun }\end{array}$ & $4.3 \pm 0.4$ & $11.2 \pm 1.9$ & 11.1 & 10.4 & 16 & 37.5 \\
\hline & Hiritiera littoralis & $1.9 \pm 0.3$ & $3.0 \pm 0.3$ & 0.1 & 1.1 & 8 & 9.2 \\
\hline \multirow{4}{*}{$\begin{array}{c}\text { Pemba- } \\
\text { Metuge } \\
\text { (PM) }\end{array}$} & $\begin{array}{c}\text { Avicennia } \\
\text { marina }\end{array}$ & $3.2 \pm 0.4$ & $13.5 \pm 2.7$ & 99.2 & 11.5 & 40.9 & 151.6 \\
\hline & Ceriops tagal & $2.1 \pm 0.0$ & $5.5 \pm 0.2$ & 0.2 & 78.8 & 27.3 & 106.2 \\
\hline & $\begin{array}{l}\text { Rhizophora } \\
\text { mucronata }\end{array}$ & $4.5 \pm 0.6$ & $8.7 \pm 2.1$ & 0 & 3.6 & 13.6 & 17.3 \\
\hline & Sonneratia alba & $4.5 \pm 0.4$ & $33.2 \pm 6.8$ & 0.6 & 6.1 & 18.2 & 24.9 \\
\hline \multirow[b]{5}{*}{ Pemba* $^{*}$} & $\begin{array}{c}\text { Avicennia } \\
\text { marina }\end{array}$ & $\mathrm{x}$ & $\mathrm{x}$ & 9.7 & 47.9 & 40.0 & 97.7 \\
\hline & $\begin{array}{l}\text { Bruguiera } \\
\text { gymnorhiza }\end{array}$ & $\mathrm{x}$ & $\mathrm{x}$ & 0.0 & 0.2 & 3.3 & 3.6 \\
\hline & Ceriops tagal & $x$ & $x$ & 2.4 & 19.4 & 16.7 & 38.4 \\
\hline & $\begin{array}{l}\text { Rhizophora } \\
\text { mucronata }\end{array}$ & $\mathrm{x}$ & $\mathrm{x}$ & 8.5 & 25.7 & 23.3 & 57.5 \\
\hline & Sonneratia alba & $x$ & $x$ & 79.4 & 6.8 & 16.7 & 102.9 \\
\hline
\end{tabular}

${ }^{*}$ Results extracted from Bandeira et al. (2009)

The most frequent diameter sizes observed at all study sites were in the diameter classes of $2.5-5$ and $5.1-10 \mathrm{~cm}$ and the largest trees were present at PM and BSE 
(Figure 2). In BSE, the diameter of trees was significantly higher $(p<0.05)$ than PM and CS. PM and CS sites were not significantly different with respect to tree diameter (Table 1 and Figure 2).

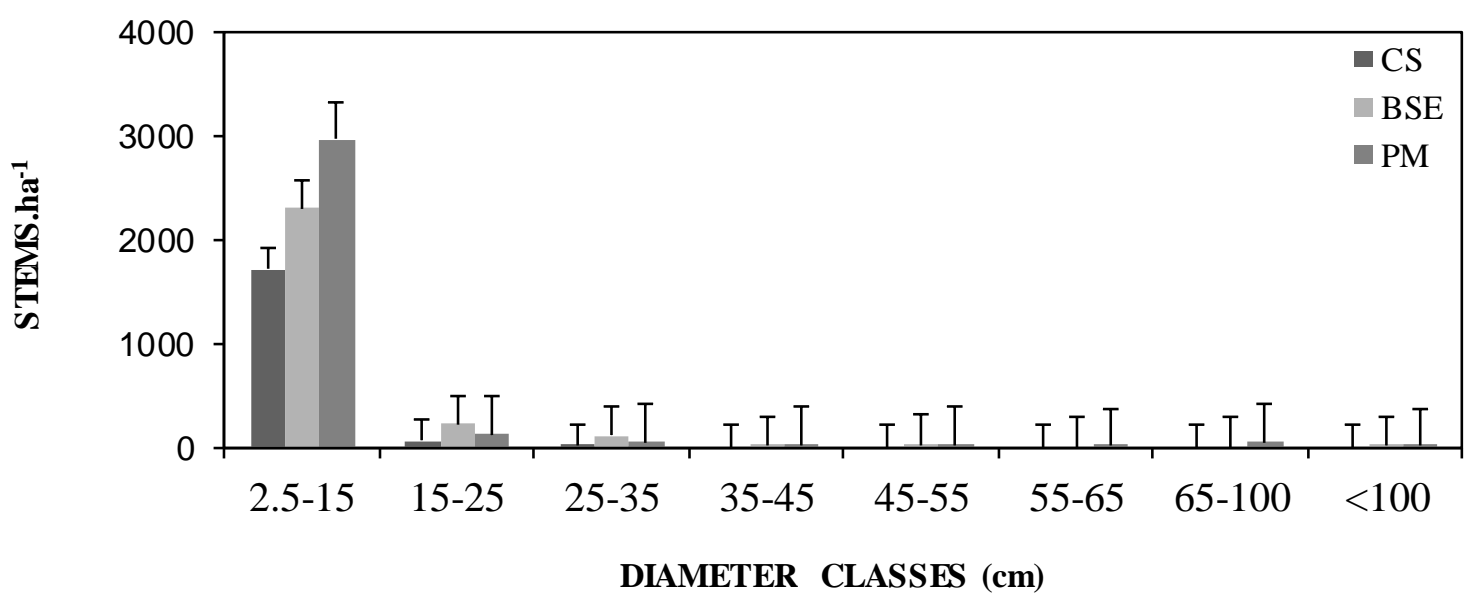

Figure 2. Diameter classes for trees $\geq 2.5 \mathrm{~cm}$ from Costa do Sol (CS), Bons Sinais Estuary (BSE) and Pemba-Metuge (PM)

The most frequently observed height size was in the $2.5-5 \mathrm{~m}$ height class. Significant differences $(p<0.05)$ in height were also observed among the different study sites. At BSE, tree height was significantly larger than at PM and CS. PM and CS were not significantly different with respect to the tree height (Table 1 and Figure 3). 


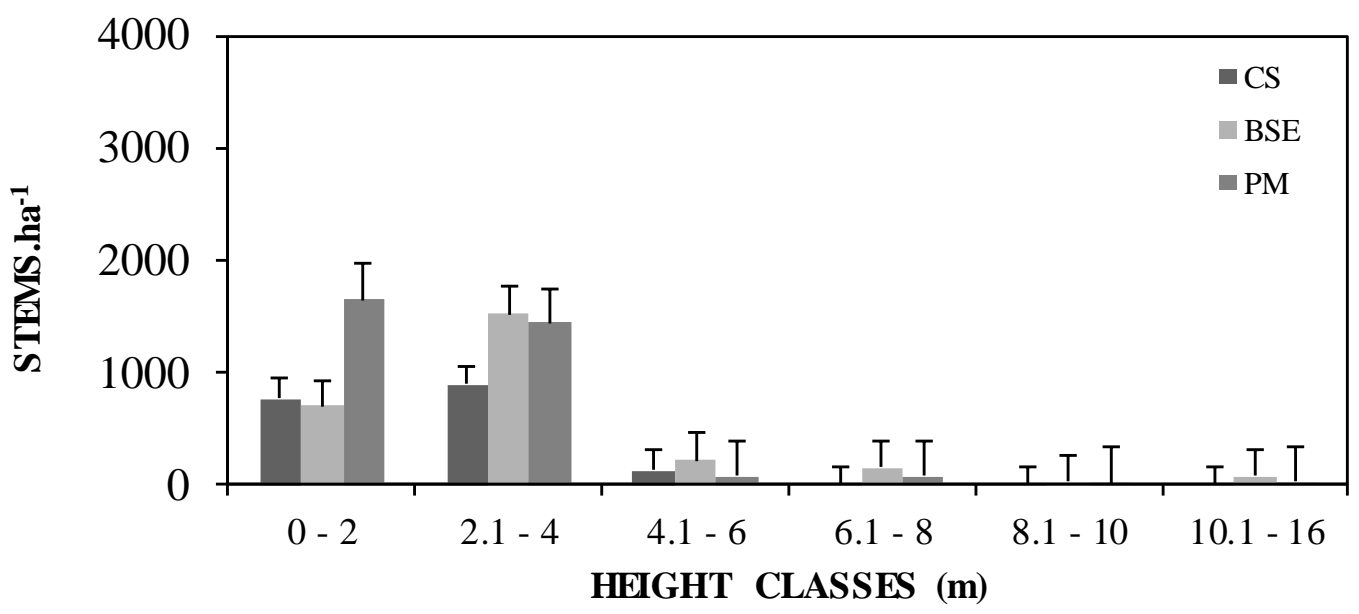

Figure 3. Height classes for trees $\geq 2.5 \mathrm{~cm}$ in diameter in Costa do Sol (CS), Bons Sinais Estuary (BSE) and Pemba-Metuge (PM)

BSE had a higher complexity index due to the higher number of species present, increased basal area and larger mean height compared to PM and CS. The mangrove forest in CS had a lower complexity than the other sites (Table 2).

Table 2. Complexity components and complexity index for all three study sites from this study as well as the information from Bandeira et al. (2009).

\begin{tabular}{|c|c|c|c|c|c|}
\hline Sites & $\begin{array}{c}\text { Number of } \\
\text { species }\end{array}$ & $\begin{array}{c}\text { Basal } \\
\text { area } \\
\left(\mathrm{m}^{2} . \mathrm{ha}^{-1}\right)\end{array}$ & $\begin{array}{c}\text { Mean } \\
\text { height } \\
(\mathrm{m})\end{array}$ & $\begin{array}{c}\text { Stem/trees } \\
\text { density } \\
\left(\mathrm{ha}^{-1}\right)\end{array}$ & $\begin{array}{c}\text { Complexity } \\
\text { index }\end{array}$ \\
\hline $\begin{array}{c}\text { Costa do Sol } \\
\text { (CS) }\end{array}$ & 3 & 24.2 & 2.3 & 1790 & 3 \\
\hline $\begin{array}{c}\text { Bons Sinais } \\
\text { Estuary (BSE) }\end{array}$ & 5 & 51.8 & 3.3 & 2680 & 22.7 \\
\hline $\begin{array}{c}\text { Pemba-Metuge } \\
\text { (PM) }\end{array}$ & 4 & 50.7 & 2.5 & 3580 & 17.9 \\
\hline Pemba & 5 & 23.03 & 3.41 & 2753 & 10.8 \\
\hline
\end{tabular}

${ }^{*}$ Results extracted from Bandeira et al. (2009) 


\section{Forest reproductive phenology}

Sampling took place during May and Avicennia marina trees were mainly dormant at PM and CS, while at BSE some trees of this species were flowering and fruiting. Ceriops tagal were mainly fruiting at PM and $R$. mucronata were flowering and fruiting at BSE. There were no significant differences $(p>0.05)$ among the three stages (dormant, flowering or fruiting) among the different localities (Figure 4).
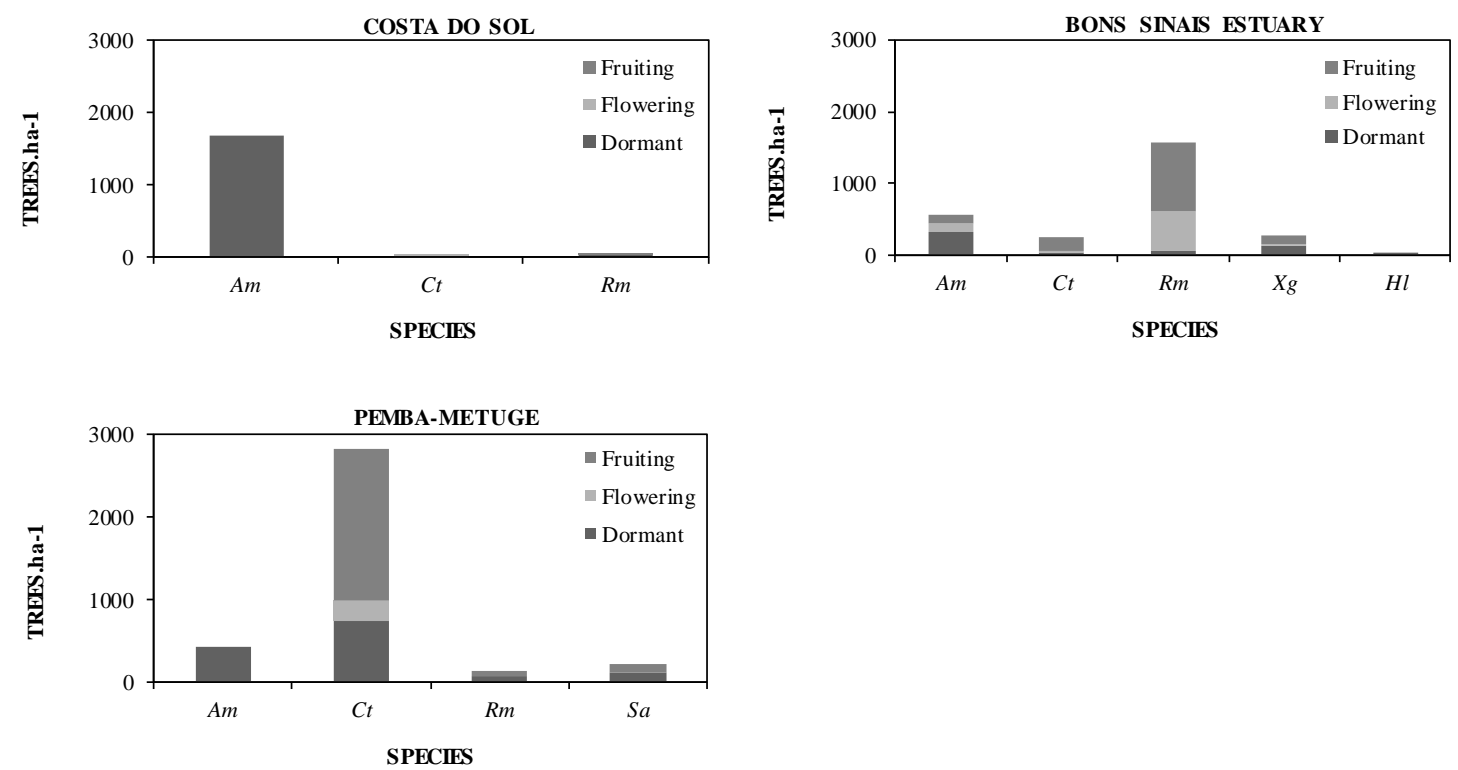

Figure 4. Reproductive phenology for trees per hectare (ha). The recorded species were Avicennia marina (Am), Ceriops tagal (Ct), Rhizophora mucronata $(R m)$, Sonneratia alba (Sa), Xilocarpus granatun $(\mathrm{Xg})$ and Heritiera littoralis $(\mathrm{HI})$

\section{Anthropogenic Disturbance}

The three sites had different types of intact tree species. At PM there were more $C$. tagal trees, while at BSE and CS there were $R$. mucronata and $A$. marina, respectively. There were more cut trees of $C$. tagal at PM, while at BSE, a higher number of cut trees were from $A$. marina and $R$. mucronata. In general, all the sites had more intact trees than partially cut trees. Both intact trees and partially cut tree status did not show significant differences $(P>0.05)$ among the three study sites (Figure 5). 

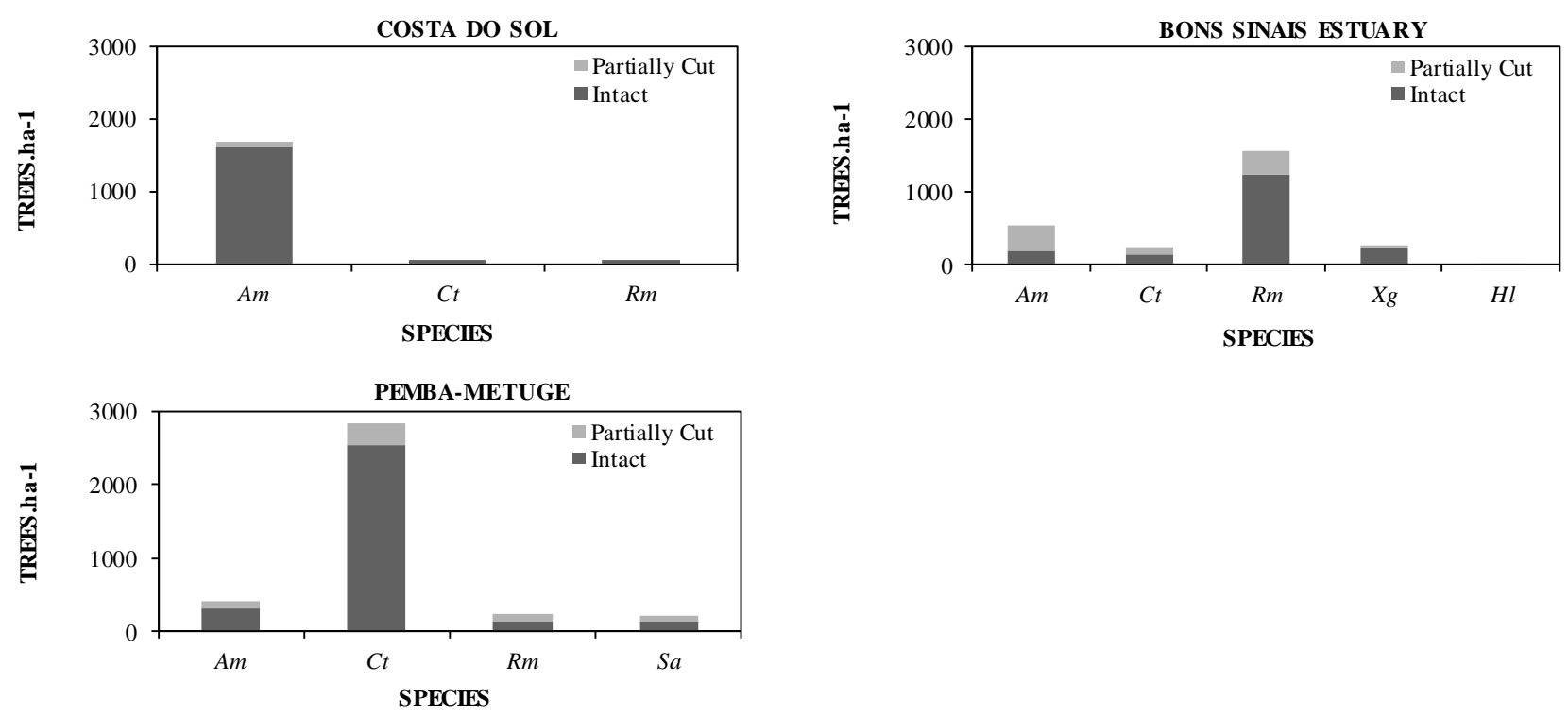

Figure 5. Deforestation status for Avicennia marina (Am), Ceriops tagal (Ct), Rhizophora mucronata $(R m)$, Sonneratia alba $(S a)$, Xilocarpus granatun $(X g)$, Heritiera littoralis $(H)$, at Costa do Sol (CS), Bons Sinais Estuary (BSE) and Pemba-Metuge (PM)

At PM and BSE, dead stumps of at least three species were observed, while at CS only dead stumps for one species was recorded, $A$. marina. The largest dead stumps, highest relative density and highest frequency of any tree species recorded were for $A$. marina at CS. The largest dead stumps observed at PM and BSE were from S. alba and A. marina, respectively. The highest density of dead stumps recorded at PM was from C. tagal and for $R$. mucronata at BSE. The most frequently cut species at PM was $C$. tagal and $A$. marina at BSE (Table 3). 
Table 3. Characteristics of the harvested trees (dead stumps) for each of the study sites.

\begin{tabular}{|c|c|c|c|c|}
\hline \multirow[b]{2}{*}{ Site } & \multirow[b]{2}{*}{ Species } & \multicolumn{3}{|c|}{ Relative values (\%) } \\
\hline & & Dominance & Density & Frequency \\
\hline $\begin{array}{l}\text { Costa do Sol } \\
\text { (CS) }\end{array}$ & $A m$ & 100.0 & 100.0 & 100.0 \\
\hline \multirow{3}{*}{$\begin{array}{l}\text { Bons Sinais } \\
\text { Estuary (BSE) }\end{array}$} & $A m$ & 65.6 & 24.3 & 47.1 \\
\hline & $C t$ & 5.2 & 22.8 & 23.5 \\
\hline & $R m$ & 29.2 & 52.9 & 29.4 \\
\hline \multirow{3}{*}{$\begin{array}{c}\text { Pemba- } \\
\text { Metuge (PM) }\end{array}$} & $C t$ & 22.6 & 98.0 & 66.7 \\
\hline & $R m$ & 0.2 & 1.3 & 22.2 \\
\hline & Sa & 77.2 & 0.4 & 11.1 \\
\hline
\end{tabular}

Avicennia marina (Am), Ceriops tagal (Ct), Rhizophora mucronata $(R m)$, Sonneratia alba (Sa)

\section{Forest regeneration}

There were generally no significant differences in the number of saplings among the study sites $(p>0.05)$ (Figure 6). Avicennia marina had more saplings in Class I (less than $40 \mathrm{~cm}$ in height) at CS. In Class II (saplings with a height of between 40.1 to 150 $\mathrm{cm}$ ) there were more saplings of $A$. marina and $R$. mucronata at BSE. In Class III (> 150 $\mathrm{cm}$ in height), there were more saplings of $C$. tagal at PM. 

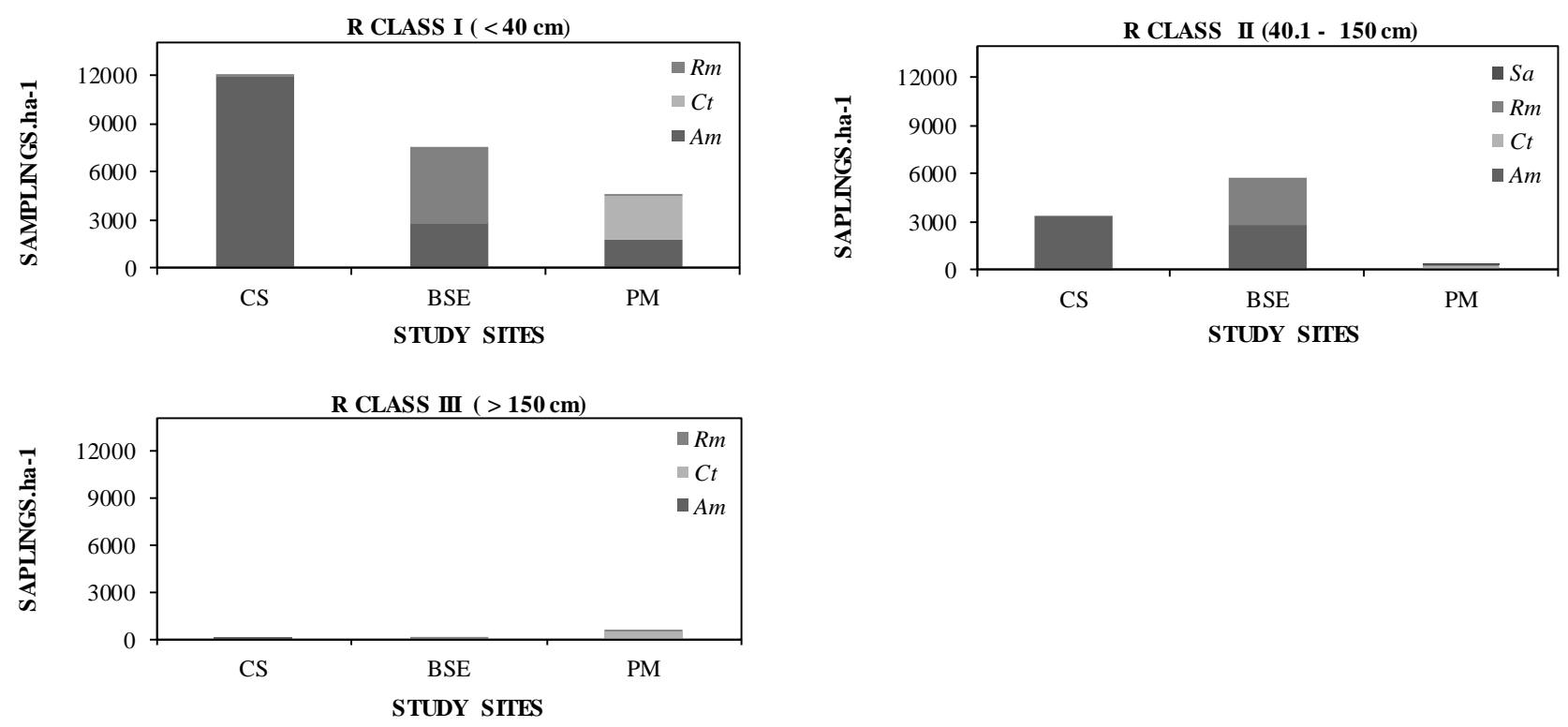

Figure 6. Regeneration status of the saplings per hectare (ha), per species, Avicennia marina $(A m)$, Ceriops tagal (Ct), Rhizophora mucronata $(R m)$, at Costa do Sol (CS), Bons Sinais Estuary (BSE) and Pemba-Metuge (PM).

\section{DISCUSSION}

This study aimed to investigate the structure of mangrove forests, at Costa do Sol (CS), Bons Sinais Estuary (BSE) and Pemba-Metuge (PM) in Mozambique. For each of these three areas, we focused on determining the importance of different species, the index of complexity of the forests, the pattern of the reproductive phenology for the species, the level of anthropogenic disturbance within each forest, the most susceptible species, as well as the regeneration pattern for the different species within the different localities. There are a limited number of similar studies from Mozambique and knowing the status of the forest structural attributes is an integral part of forest management and conservation planning (Sapkota, Stahl, \& Norton, 2018).

Mangrove forests at CS had a low complexity, probably because this area is part of the Maputo urban limit with higher anthropogenic pressure. It is possible that some activities 
in this area do not allow for development of the forest. Penha-Lopes et al. (2009) reported that this area receives domestic sewage, aquaculture residues and solid waste from various sources. In addition, mangroves have been removed to provide space for building houses, for aquaculture ponds/dams and cutting of trees for poles and firewood. These activities have already been described by Ferreira \& Lacerda (2016) and HimesCornell, Pendleton, \& Atiyah (2018) to have a high impact on mangrove degradation (Table 1 and 2).

PM and BSE had a diverse distribution of species, a pattern that is usually seen in sites where the species zonation and composition experience little disturbance. BSE had tall A. marina and PM tall $S$. alba that act as pioneer species on fringing mudflats. Both these sites had a mix of $R$. mucronata, $C$. tagal and Bruguiera gymnorrhiza communities and $A$. marina scrub communities on the landward border of the forest. This type of pattern has also been reported for other Mozambican mangrove forests (Fatoyinbo, Simard, Washington-Allen, \& Shugart, 2008; Bandeira et al., 2009).

In total, seven mangrove species were identified in this study out of eight true mangrove species recorded from Mozambique (Barbosa, Cumbe, \& Bandeira, 2001; Stringer, Trettin, Zarnoch, \& Tang, 2015). Although B. gymnorrhiza was not recorded in the plots during our sampling, B. gymnorrhiza was seen at all three study sites. Bandeira et al. (2009) recorded very low densities for this species in some mangroves in the southern and northern parts of Mozambique. For this study, transects were established randomly and our plots were marked along transects to collect a representative sample of the forest. It is most likely due to the low density of $B$. gymnorhiza in our study sites that they were excluded from our collected samples. The low density might be due to the fact that the areas sampled, overlap slightly or fall outside the preferred range of conditions for $B$. gymnorhiza. Kathiresan \& Bingham (2001) pointed out that the factors affecting the 
distribution of mangroves include: temperature, moisture, large-scale currents, propagules viability, establishment success and growth rate. Bruguiera gymnorrhiza was reported to form a significant component of many Pacific mangrove swamps (Krauss \& Allen, 2003) and probably prefer the Pacific conditions.

Avicennia marina at CS and PM most likely completed its reproductive cycle before the sampling took place since these trees were mainly in a dormant stage during May (when sampling was performed). Amade (2006) reported that at CS, this species was flowering and fruiting between March and April. In contrast, some $A$. marina trees at BSE were flowering and fruiting. This corresponds to what Wium-Andersen \& Christensen (1978) observed for A. marina trees from Phuket Island inThailand, where this species had flowers during April and May. Wang'ondu et al. (2010) reported that bud initiation for $A$. marina from Kenya took place between November and March, after which they started to produce flowers and had their peak fruit production between April and May.

Ceriops tagal trees were flowering and fruiting in the month of May at PM. This was earlier compared to what was found by Wium-Andersen \& Christensen (1978). In their study, they found that floral buds appeared between April and May and that the trees flowered during June. However, Amade (2006) observed that $R$. mucronata and $C$. tagal from Maputo Bay flowered and were fruiting throughout the year. In addition, $R$. mucronata trees were observed to be flowering and fruiting at the same time at BSE. It appears that the $R$. mucronata trees at BSE were flowering slightly earlier when compared to trees from Kenya, which showed a dramatic increase in flowering during April and May (Wang'ondu et al., 2013). Thus, timing of mangrove reproduction seems to depend on local environmental conditions and may differ broadly over the species range (Kathiresan \& Bingham, 2001). 
At PM and BSE, dead stumps of at least three species were observed ( $A$. marina, $C$. tagal, $R$. mucronata), while at CS only dead stumps for $A$. marina were recorded. The largest dead stumps were for $A$. marina at CS. The largest dead stumps observed at PM and BSE were from $S$. alba and $A$. marina, respectively. It was clearly visible that the type of species and sizes of trees preferred for cutting was different among the study sites. The usage and dependence on mangrove resources happen according to the availability of resources and as a function of forest physiography (Dos Santos \& Lana, 2017), the quality of wood and the available sizes (Dahdouh-Guebas, Mathenge, Kairo, \& Koedam, 2000). Since local people use mangroves for subsistence and have speciesuse preferences, this most probably results in selective logging of trees as well as selective removal of tree parts (Dahdouh-Guebas \& Koedam, 2006). The high level of dependency on mangrove resources can lead to the higher pressure of harvesting. Abdullah, Tacey, Garnett, \& Myers (2016) reported that the level of dependency on forest resources, among households with access to forests, could vary from six to $65 \%$ depending on the local circumstances. It is clear that human activities have an accumulated effect on the structure and condition of the mangrove forests (Bandeira et al. 2009).

Activities having a negative impact on mangroves in each of the study sites include agriculture, aquaculture (Mazzilli, 2015), salt pans and points of charcoal production at BSE, human settlements and fishing points at PM, and a residential area surrounding the mangrove at CS. Dos Santos \& Lana (2017) reported on a similar case of the utilization of some species of Rhizophora, suitable for firewood and for tannin extraction in Brazil. Dahdouh-Guebas, Mathenge, Kairo, \& Koedam (2000) also reported on many uses of mangrove species from Kenya for $R$. mucronata, $C$. tagal and B. gymnorrhiza, where these species were preferred for boat, canoe and house construction because of their characteristic straight-growing. Rhizophora mucronata roots are being used for their healing properties. Sonneratia alba ribs are specifically used to build traditional dhows. 
Avicennia marina's timber is being used to build houses and boats, produce insecticides and preferably used by fishermen to make fire since its wood is slow burning (DahdouhGuebas, Mathenge, Kairo, \& Koedam, 2000).

Avicennia marina had more Class I saplings (less than $40 \mathrm{~cm}$ in height) at CS. This site had a lower complexity and a more open canopy that allowed more light to penetrate and reaching the substrate, promoting more growth. This is supported by Peng et al. (2016) who reported that the absence of light was one of the main limiting factors in early growth for mangroves. Krauss (2008) concluded that light gaps are important for mangrove forest development. In addition, Tamin, Zakaria, Hashim, \& Yin (2011) reported that $A$. marina growing under closed forest conditions exhibited a stunted form.

Avicennia marina was the most dominant species with saplings in all three regeneration classes, pointing to the higher capacity for regeneration that is similar to what was reported by Bandeira et al. (2009). This is probably due to its high fecundity and ability to grow and reproduce across a broad range of environmental conditions, tolerating a wide range of salinity, light intensity, intertidal positions and temperature fluctuations (ArnaudHaond et al., 2006; Tamin, Zakaria, Hashim, \& Yin, 2011; Almahasheer, Duarte, \& Irigoien, 2016). Furthermore, the average annual supply of propagules of $A$. marina over a lifetime is about 247 viable propagules per tree, after taking into account the high predispersal mortality of floral buds and fruits due to larval attack and storms (Clarke, 1992; Tamin, Zakaria, Hashim, \& Yin, 2011).

Recommendations for similar studies, without limited resources, would include more sampling plots specifically in BSE, as this is a larger area than CS and PM, in order to sample more representatively. The use of a different sampling strategy could be considered in order to overcome certain challenges in the landscape such as dense 
vegetation, creeks, muddy and wet soil. Also, a social-economic study that specifically focusses on each of the local communities with regards to the community's dependence on the mangroves, their uses and preferences will positively contribute to understanding these complex systems.

\section{CONCLUSIONS}

This study recorded a total of seven species of mangroves, with the Bons Sinais Estuary (BSE) mangrove forest having the highest number of species, the greatest mean height, as well as the highest complexity compared to Costa do Sol (CS) and Pemba-Metuge (PM). Avicennia marina was identified as the most ecologically important species in all three study sites, with the highest capacity for regeneration making it potentially a candidate species for reforestation schemes of mangrove forests. During the month of May, A. marina trees were mainly dormant at CS while flowering and fruiting at BSE. Ceriops tagal at PM and R. mucronata at BSE were flowering and fruiting during May, showing variation in the reproductive cycles per species at the different study sites.

The evaluation of the level of anthropogenic disturbance showed that intact trees were dominant within all three study sites. The preferred species for cutting by the local community at CS and BSE was A. marina, and R. mucronata, C. tagal and S. alba in PM. This study also demonstrated the preferences of the local community for cutting down the whole tree instead of parts of the tree, and that the type of species depended on the people from the area.

\section{ACKNOWLEDGEMENTS}

We would like to thank Mozambican National Research Fund from Ministério de Ciência e Tecnologia, Ensino Superior e Técnico Profissional de Moçambique for funding this research. The School of Coastal and Marine Science of Eduardo Mondlane University, 
Research Center in Marine Environment of Pemba tutored by Ministério da Terra,

Ambiente e Desenvolvimento Rural for their support during the realization of this work.

\section{REFERENCES}

Abdullah, A. N. M., Tacey, N., Garnett, S. T., \& Myers, B. (2016). Economic dependence on mangrove forest resources for livelihoods in the Sundarbans, Bangladesh. Forest Policy, 64, 15-24.

Amade, F. M. C. (2006). Study of three communities of mangroves (Avicennia marina, Ceriops tagal and Rhizophora mucronata) in three sites at Maputo Bay, Costa do Sol, Ponta Rasa and Saco da Inhaca. Eduardo Mondlane University, Maputo, Mozambique.

Amade, F. M. C. (2008). Study of structure, conservation status and environmental factors, in two mangrove forests: Espírito Santo Estuary and Saco da Inhaca. Eduardo Mondlane University, Maputo, Mozambique.

Almahasheer, H., Duarte, C. M., \& Irigoien, X. (2016). Phenology and growth dynamics of Avicennia marina in the Central Red Sea. Scientific Reports, 6, 1-9.

Arnaud-Haond, S., Teixeira, S., Massa, S. I., Billot, C., Saenger, P., Coupland, G., et al. (2006). Genetic structure at range edge: low diversity and high inbreeding in Southeast Asian mangrove (Avicennia marina) populations. Molecular Ecology 15, 3515-3525.

Bandeira, S. O., Macamo, C. C. F., Kairo, J. G., Amade, F., Jiddawi, N., \& Paula, J. (2009). Evaluation of mangrove structure and condition in two trans-boundary areas in 
the Western Indian Ocean. Aquatic Conservation: Marine and Freshwater Ecosystems 19, 46-55.

Barbosa, F. M. A., Cumbe, C. C., \& Bandeira, S.O. (2001). Status and distribution of mangroves in Mozambique. South African Journal of Botany, 67, 393-398.

Barnuevo, A., Asaeda, T., Sanjaya, K., Kanesaka, Y., \& Fortes, M. (2017). Drawbacks of mangroves rehabilitation schemes: lessons learned from large-scale mangrove plantations. Estuarine, Coastal and Shelf Science, 198, 432-437.

Bosire, J. O., Dahdouh-Guebas, F., Kairo, J. G., \& Koedam, N. (2003) Colonization of non-planted mangrove species into restored mangrove stands in Gazi Bay, Kenya. Aquatic Botany, 76, 267-279.

Brown, M. I., Pearce, T., Leon, J., Sidle, R., \& Wilson, R. (2018). Using remote sensing and traditional ecological knowledge (TEK) to understand mangrove change on the Maroochy River, Queensland, Australia. Applied Geography, 94, 71-83.

Brokaw, N., \& Thompson, J. (2000). The H for DBH. Forest Ecology and Management 129, 89-91.

Canhanga, S., \& Dias, J. M. (2005). Tidal characteristics of Maputo Bay, Mozambique. Journal of Marine Systems, 58, 83-97.

Cannicci, S., Bartolini, F., Dahdouh-Guebas, F., Fratini, S., Litulo, C., Macia, A., et al. (2009). Effects of urban wastewater on crab and mollusc assemblages in equatorial and 
subtropical mangroves of East Africa. Estuarine, Coastal and Shelf Science, 84, 305317.

Cintron, G., \& Schaeffer-Novelli, Y. (1984). Methods for studying mangrove structure. In: Snedaker, S.C., Snedaker, J. G. (Eds.), The Mangrove ecosystem: Research Methods. Paris, France, UNESCO.

Clarke, P. J. (1992). Pre - dispersal mortality and fecundity in the grey mangrove (Avicennia marina) in Southeast Australia. Australian Journal of Ecology, 17, 161-168.

Curtis, J. T. (1959). The vegetation of Wisconsin. An Ordination of plant communities. Madison, Wisconsin, USA University of Wisconsin Press.

Dahdouh-Guebas, F., Mathenge, C., Kairo, J. G., \& Koedam, N. (2000). Utilization of mangrove wood products around Mida Creek (Kenya) among subsistence and commercial users. Economic Botany, 54, 513-527.

Dahdouh-Guebas, F., \& Koedam, N. (2006). Empirical estimate of the reliability of the use of the Point-Centred Quarter Method (PCQM): solutions to ambiguous field situations and description of the PCQM+ protocol. Forest Ecology and Management, 228, 1-18.

Dos Santos, N. M., \& Lana, P. (2017). Present and past uses of mangrove wood in the subtropical Bay of Paranagua (Parana, Brazil). Ocean \& Coastal Management, 148, 97103. 
Fatoyinbo, T. E., Simard, M., Washington-Allen, R. A., \& Shugart, H. H. (2008). Landscape-scale extent, height, biomass, and carbon estimation of Mozambique's mangrove forests with Landsat ETM+ and Shuttle Radar Topography Mission elevation data. Journal of Geophysical Research, 113, 1-13.

Fenner, M. (1998) The phenology of growth and reproduction in plants. Perspectives in Plant Ecology Evolution and Systematics, 1, 78-91.

Ferreira, A. C., \& Lacerda, L. D. (2016). Degradation and conservation of Brazilian mangroves, status and perspectives. Ocean \& Coastal Management, 125, 38-46.

Garcia, J. S., Dalmolin, A. C., França, M. G. C., \& Mangabeira, P. A. O. (2017). Different salt concentrations induce alterations both in photosynthetic parameters and salt gland activity in leaves of the mangrove Avicennia schaueriana. Ecotoxicology and Environmental Safety, 141, 70-74.

Giri, C.E., Ochieng, L.L., Tieszen, Z., Zhu, A., Singh, T., Loveland, J., et al. (2013). Global Mangrove distribution, 2000, Palisades, NY; Nasa socioeconomic data and application center (CEDAC). Retrivied $24^{\text {th }}$ October, 2018, from http://sedac.ciesin.columbia.edu/data/set/lulc-global-mangrove-forests-distribution2000/maps.

Himes-Cornell, A., Pendleton, L., \& Atiyah, P. (2018). Valuing ecosystem services from blue forests: A systematic review of thevaluation of salt marshes, seagrass beds and mangrove forests Ecosystem Services, 30, 36-48. 
Holdridge, L., Grenke, W. C., Hatheway, W. H., Liang, T., \& Tosi, J. A. (1971). Forest Environment in Tropical Life Zones. New York, NY: Pergamon Press.

Kairo, J. G., Dahdouh-Guebas, F., Gwada, P. O., Ochieng, C., \& Koedam, N. (2002). Regeneration Status of Mangrove Forests in Mida Creek, Kenya: A Compromised or Secured Future?. Ambio, 31, 562-568.

Kairo, J. G., Lang'at, J. K. S., Dahdouh-Guebas, F., Bosire, J., \& Karachi, M. (2008). Structural development and productivity of replanted mangrove plantations in Kenya. Forest Ecology and Management, 255, 2670-2677.

Kathiresan, K., \& Bingham, B.L. (2001). Biology of mangroves and mangrove ecosystems 2. Advances in Marine Biology, 40, 81-251.

Krauss, K. W., Lovelock, C. E., McKee, K. L., Lópes-Hoffman, L., Ewe, S. M. L., \& Sousa, W.P. (2008). Environmental drivers in mangrove establishment and early development: A review. Aquatic Botany, 89, 105-127.

Krauss, K. W., \& Allen, J. A. (2003). Factors influencing the regeneration of the mangrove Bruguiera gymnorrhiza (L.) Lamk. on a tropical Pacific Island. Forest Ecology and Management, 176, 49-60.

Litulo, C. (2005a). Population biology of the fiddler crab Uca annulipes (Brachyura: Ocypodidae) in a tropical East African mangrove (Mozambique). Estuarine, coastal and shelf Sciences, 62, 283-290. 
Mazzilli, S. (2015). Understanding estuarine hydrodynamics for decision making in datapoor coastal environments. University of Cambridge. Cambridge, UK.

Mocuba, J. J. (2010). Dissolved oxygen and biochemical oxygen demand in the waters close to the Quelimane sewage discharge. University of Bergen. Bergen, Norway.

Pastor-Guzman, J., Dash, J., \& Atkinson, P. M. (2018). Remote sensing of mangrove forest phenology and environmental drivers. Remote Sensing of Environment, 205, 7184.

Peng, Y., Diao, J., Zheng, M., Guan, D., Zhang, R., Chen, G., et al. (2016). Early growth adaptability for four mangrove species under the canopy of an introduced mangrove plantation: implications for restoration. Forest Ecology and Management, 373, 179-188.

Penha-Lopes, G., Torres, P., Narciso, L., Cannicci, S., \& Paula, J. (2009). Comparison of fecundity, embryo loss and fatty acid composition of mangrove crab species in sewagecontaminated and pristine mangrove habitats in Mozambique. Journal of Experimental Marine Biology and Ecology, 381, 25-32.

Penha-Lopes, G., Torres, P., Cannicci, S., Narciso, L., \& Paula, J. (2011). Monitoring anthropogenic sewage pollution on mangrove creeks in southern Mozambique: A test of Palaemon concinnus Dana, 1852 (Palaemonidae) as a biological indicator. Environmental Pollution, 159, 636-645.

Sahu, S. K., Singh, R., \& Kathiresan, K. (2016). Multi-gene phylogenetic analysis reveals the multiple origin and evolution of mangrove physiological traits through exaptation. Estuarine, Coastal and Shelf Science, 183, 41-51. 
Sapkota, R.P., Stahl, P.D., \& Norton, U. In Press. Anthropogenic disturbances shift diameter distribution of wood plant species in Shora robusta Gaerth. (sal) mixed forest of Nepal. Journal of Asia-Pacific Biodiversity.

Sengo, D. J., Kachapila, A., Van Der Zaag, P., Mul, M., \& Nkomo, S. (2005). Valuing environmental water pulses into the Incomati estuary: Key to achieving equitable and sustainable utilization of transboundary waters. Physics and Chemistry of the Earth, 30, 648-657.

Stringer, C. E., Trettin, C. C., Zarnoch, S. J., \& Tang, W. (2015). Carbon stocks of mangroves within the Zambezi River Delta, Mozambique. Forest Ecology and Management, 354, 139-148.

Utui, J., Macuácua, N., Mandlate, T., Boina, J., Raposo, R. C. V., Machava, C., et al. (2013). Statistics of Pemba-Metuge District, Cabo Delgado Province. Mozambican National Institute of Statistics. Maputo, Moçambique.

Urrego, L. E., Molina, E. C., \& Suárez, J. A. (2014). Environmental and anthropogenic influences on the distribution, structure, and floristic composition of mangrove forests of the Gulf of Urabá (Colombian Caribbean). Aquatic Botany, 114, 42-49.

Tamin, N. M., Zakaria, R., Hashim, R., \& Yin, Y. (2011). Establishment of Avicennia marina mangroves on accreting coastline at Sungai Haji Dorami, Selangor, Malasia. Estuarine, Coastal Shelf Science, 94, 334-342.

Tomlinson, P.B. (1986) The botany of mangroves. Cambridge University Press. 
Wang'ondu, V. W., Kairo, J. G., Kinyamario, J. I., Mwaura, F. B., Bosire, J. O., DahdouhGuebas, F., et al. (2010). Phenology of Avicennia marina (Forsk.) Vierh. in a disjunctlyzoned mangrove stand in Kenya. Western Indian Ocean Journal of Marine Sciences, 9, $135-144$.

Wang'ondu, V. W., Kairo, J. G., Kinyamario, J. I., Mwaura F. B., Bosire, J. O., DahdouhGuebas F., et al. (2013) Vegetative and reproductive phenological traits of Rhizophora mucronata Lamk. And Sonneratia alba Sm. Flora, 208, 522-531.

Wium-Andersen, S., \& Christensen, B. (1978). Seasonal growth of mangrove trees in southern Thailand. II. Phenology of Bruguiera cylindrica, Ceriops tagal, Lumnitzera littorea and Avicennia marina. Aquatic Botany, 5, 383-390. 